\title{
Shewanella woodyi sp. nov., an Exclusively Respiratory Luminous Bacterium Isolated from the Alboran Sea
}

\author{
JOHN C. MAKEMSON,${ }^{1 *}$ NADA R. FULAYFIL, ${ }^{1}$ WARREN LANDRY, ${ }^{2}$ LISA M. VAN ERT, ${ }^{3}$ \\ CHARLES F. WIMPEE, ${ }^{3}$ EDITH A. WIDDER, ${ }^{4}$ AND JAMES F. CASE ${ }^{5}$ \\ Department of Biological Sciences, Florida International University, University Park, Miami, Florida $33199^{1}$; \\ Food and Drug Administration, Dallas, Texas 752042; Department of Biological Sciences, University of \\ Wisconsin-Milwaukee, Milwaukee, Wisconsin 53201 ${ }^{3}$; Harbor Branch Oceanographic Institution, \\ Fort Pierce, Florida 34946 ; and Bioluminescence Group, Marine Science Institute, \\ University of California, Santa Barbara, California $93106^{5}$
}

\begin{abstract}
Thirty-four strains of nonfermentative, respiratory, luminous bacteria were isolated from samples of squid ink and seawater from depths of 200 to $300 \mathrm{~m}$ in the Alboran Sea. Although these strains had a few properties similar to properties of Shewanella (Alteromonas) hanedai, they did not cluster phenotypically with any previously described bacterium. The nucleotide sequence of a 740-bp segment of lux $A$ was not homologous with other known luxA sequences but clustered with the luxA sequences of Shewanella hanedai, Vibrio logei, Vibrio fischeri, and Photobacterium species. The 16S RNA gene from two strains was sequenced and was found to be most closely related to the $S$. hanedai 16S RNA gene. Based on the differences observed, we describe the new isolates as members of a new species, Shewanella woodyi sp. nov. Strain ATCC 51908 (= MS32) is the type strain of this new species.
\end{abstract}

The first isolates of exclusively respiratory (nonfermentative) marine luminous bacteria were assigned to Alteromonas hanedai $(2,5 \mathrm{a})$ and later were reassigned to the genus Shewanella $(5 \mathrm{~b}, 9)$. The genus Shewanella is composed of four species, and only one of these species, Shewanella hanedai, is bioluminescent. Compared to species of the genera Alteromonas, Pseudomonas, and Deleya, S. hanedai and Shewanella putrefaciens have unique quinone compositions, and these organisms possess menaquniones that are not present in Alteromonas species (1). Further confirmation that these Shewanella species form an independent clade that can be recognized as a genus came from $16 \mathrm{~S}$ rRNA sequence analysis (4).

Water samples and squid ink samples from intermediatedepth dives of the submersible Johnson Sea Link contained luminous bacteria that were found to be unable to ferment sugars but could grow anaerobically with nitrate or nitrite as a terminal electron acceptor. Because these organisms did not seem to be similar to $S$. hanedai, we performed a more complete phenotypic characterization along with a hybridization and sequence analysis of a 740-bp section of the $\operatorname{lux} A$ gene, and we also sequenced the $16 \mathrm{~S}$ RNA gene from two strains. We designated these new isolates Shewanella woodyi $\mathrm{sp}$. nov. The species name is in honor of J. Woodland Hastings, known to most as Woody, an American biologist who, among other things, has made numerous and valuable contributions to our understanding of the biochemistry and function of bacterial bioluminescence.

\section{MATERIALS AND METHODS}

All of the strains analyzed in this study (Table 1) were picked as luminous bacterial colonies after squid ink, seawater, or detritus was plated from samples taken at depths of 200 to $430 \mathrm{~m}$ during three dives $\left(35^{\circ} 29.05^{\prime} \mathrm{N}, 4^{\circ} 26.40^{\prime} \mathrm{W}\right.$ for dives 2929 and $2930 ; 35^{\circ} 45.34^{\prime} \mathrm{W}, 2^{\circ} 45.42^{\prime} \mathrm{W}$ for dive 2942 ) of the submersible Johnson Sea Link in the Alboran Sea by two of us (E.A.W. and J.F.C.). The luminous isolates were restreaked and purified on glycerol marine agar (GMA) containing (per liter) $3 \mathrm{ml}$ of glycerol, $5 \mathrm{~g}$ of Bacto Peptone (Difco), $1 \mathrm{~g}$ of Bacto Yeast Extract (Difco), $15 \mathrm{~g}$ of Bacto Agar (Difco), and 0.5× sea salts (pH 7.5) The sea salts preparation was made as a $5 \times$ stock solution $(2.58 \mathrm{M} \mathrm{NaCl}, 0.125$

\footnotetext{
*Corresponding author. E-mail: makemson@squ.edu.
}

$\mathrm{M} \mathrm{MgCl}_{2}, 0.125 \mathrm{M} \mathrm{MgSO}_{4}, 0.1 \mathrm{M} \mathrm{KCl}$ ) and was diluted 1:10 in the medium. Our previous experience with luminous marine bacteria indicated that this medium was suitable for most luminous marine bacteria; however, $S$. woodyi grew but did not produce luminescence in GMA broth (this was later shown to be due to a salt requirement for luminescence). We also found that the strains whose designations begin with MS (MS strains) did not utilize glycerol. Consequently, the medium used for these strains was changed to Shewanella marine agar (SMA) containing (per liter) $5 \mathrm{~g}$ of Bacto Peptone (Difco), $1 \mathrm{~g}$ of Bacto Yeast Extract (Difco), $15 \mathrm{~g}$ of Bacto Agar (Difco), and $1 \times$ sea salts ( $\mathrm{pH} 7.5$ ). The designations used for the $S$, woodyi isolates all begin with MS, and strains of other luminous marine bacteria either were maintained as frozen glycerol stock preparations or were kept on slants of GMA or SMA

Our phenotypic characterization included determining the growth temperature (by using $4,25,37$, and $42^{\circ} \mathrm{C}$ ) on either GMA or SMA and performing tests for hydrolases (amylase, gelatinase, lipase, chitinase) (by using the methods of Reichelt and Baumann [11]), oxidase, catalase, API 20E reactions (Analytab Products), luciferase kinetics (10), and the Biolog substrates (Biolog, Inc., Hayward, Calif.). For the API 20E test strip study, as well as the Biolog GN plate study, $S$. woodyi strains were grown on SMA and suspended in $1 \times$ sea salts, whereas the other strains were grown on GMA and suspended in $0.5 \times$ sea salts. For bacteria that grew equally well on both media, no difference between the reaction patterns with the Biolog substrates was noticed when inocula were prepared with the two procedures. The Biolog database could not be used for identification because it was derived from the reactions of cells grown on a different medium and suspended in standard saline rather than seawater salts. Furthermore, all of the previously described bacteria (Table 1) used in this study gave Biolog reactions that were different from the reactions in the Biolog database.

The phenotypic characterization data were codified to obtain 131 traits, which included Gram staining and morphology (5 traits). The following traits were used in a cluster analysis: Gram stain reaction (trait no. 1), morphology (trait no. 2 through 4 ), growth temperatures $\left(4,25,37\right.$, and $42^{\circ} \mathrm{C}$ ) (trait no. 5 through 8 ), hydrolase activities (amylase, gelatinase, lipase, and chitinase activities) (trait no. 9 through 12), oxidase and catalase activities (trait no. 13 and 14), API 20E reactions (trait no. 15 through 34 ), luciferase kinetics (trait no. 35 and 36 ), and Biolog substrate utilization (95 substrates) (trait no. 37 through 131). Clusters were analyzed by using cluster analysis (unweighted pair group method with arithmetic means [UPGMA]) to determine Euclidian distances and then multidimensional scaling with the distance matrix produced by Cluster Analysis in the STATISTICA 4.5 program (StatSoft, Tulsa, Okla.). Representative strains of clusters were tested with the MIDI (fatty acid analysis) system for relatedness to themselves and known strains in a marine bacterial library by one of us (W.L.).

lux $A$ probes were amplified from either chromosomal DNA (S. woodyi MS32 ${ }^{\mathrm{T}}$ ) or Vibrio harveyi luxAB on plasmid pLAV1 (a gift from T. O. Baldwin, Texas A and M University) in Escherichia coli LE392 by using standard PCR techniques (14) under stringent $\left(55^{\circ} \mathrm{C}\right)$ and nonstringent $\left(35^{\circ} \mathrm{C}\right)$ annealing conditions with the $\operatorname{lu} x A$ primers of Wimpee et al. (14). Amplified DNA was random prime labeled with digoxigenin as described by the manufacturer (Boerhinger Mannheim) and was used as a probe to hybridize chromosomal or plasmid DNA. The PCR product was sequenced with an Amplitaq cycle sequencing kit (Perkin- 
TABLE 1. Sources of $S$. woodyi strains and other bacteria ${ }^{a}$

\begin{tabular}{|c|c|c|}
\hline Taxon & Strain(s) & Source $^{b}$ \\
\hline Alteromonas haloplanktis & ATCC $14393^{\mathrm{T}}$ & ATCC \\
\hline Escherichia coli & $\mathrm{B}$ & $\begin{array}{r}\text { FIU Culture } \\
\text { Collection }\end{array}$ \\
\hline Photobacterium angustum & ATCC $25915^{\mathrm{T}}$ & ATCC \\
\hline Photobacterium leiognathi & $\begin{array}{l}\text { ATCC } 25521^{\mathrm{T}} \\
721\end{array}$ & $\begin{array}{l}\text { ATCC } \\
\text { Kenneth Nealson }\end{array}$ \\
\hline Photobacterium phosphoreum & ATCC $11040^{\mathrm{T}}$ & ATCC \\
\hline Shewanella hanedai & ATCC $33224^{\mathrm{T}}$ & ATCC \\
\hline Shewanella putrefaciens & ATCC $8071^{\mathrm{T}}$ & ATCC \\
\hline \multirow[t]{6}{*}{ Shewanella woodyi } & $\begin{array}{l}\text { MS1, MS7 through } \\
\text { MS11 }\end{array}$ & $\begin{array}{l}\text { Dive } 2929,435 \mathrm{~m} \text {, } \\
\text { squid ink }\end{array}$ \\
\hline & MS15 through MS18 & $\begin{array}{l}\text { Dive } 2930,198 \mathrm{~m} \text {, } \\
\text { seawater }\end{array}$ \\
\hline & MS19 through MS30 & $\begin{array}{l}\text { Dive } 2942,220 \mathrm{~m} \text {, } \\
\text { seawater }\end{array}$ \\
\hline & MS31 through MS34 & $\begin{array}{l}\text { Dive } 2942,370 \mathrm{~m} \text {, } \\
\text { detritus }\end{array}$ \\
\hline & MS35 through MS38 & $\begin{array}{l}\text { Dive } 2942,384 \mathrm{~m} \text {, } \\
\text { seawater }\end{array}$ \\
\hline & MS39 through MS41 & $\begin{array}{l}\text { Dive } 2942,370 \mathrm{~m} \text {, } \\
\text { seawater }\end{array}$ \\
\hline Vibrio alginolyticus & $\operatorname{ATCC} 17749^{\mathrm{T}}$ & ATCC \\
\hline Vibrio anguillarum & & Richard Morita \\
\hline Vibrio carchariae & ATCC $35084^{\mathrm{T}}$ & ATCC \\
\hline Vibrio cholerae 01 & ATCC $14035^{\mathrm{T}}$ & ATCC \\
\hline Vibrio cholerae El Tor & ATCC 14033 & ATCC \\
\hline Vibrio fischeri & ATCC $7744^{\mathrm{T}}$ & ATCC \\
\hline Vibrio harveyi & B-392, MAV & J. W. Hastings \\
\hline Vibrio logei & MS12 & $\begin{array}{l}\text { Dive } 2929,435 \mathrm{~m} \text {, } \\
\text { squid ink }\end{array}$ \\
\hline Vibrio $n$ & ATCC $14048^{\mathrm{T}}$ & ATCC \\
\hline Vibrio parahaemolyticus & $\mathrm{B} 22$ & $\begin{array}{l}\text { Michael } \\
\text { Silverman }\end{array}$ \\
\hline Vibrio vulnificus & ATCC $27562^{\mathrm{T}}$ & ATCC \\
\hline
\end{tabular}

${ }^{a}$ Other strains that were used included Vibrio harveyi-like strains from Bahrain, the Gulf of Oman, and Biscayne Bay and strains WH69 and WH70, which are undescribed Photobacterium strains isolated from the Gulf of California by Paul Dunlap.

${ }^{b}$ ATCC, American Type Culture Collection; FIU, Florida International University.
Elmer Cetus) by using the methods recommended by the manufacturer. A phylogenetic analysis in which heuristic methods were used was performed by using the PAUP program (12).

The DNA G + C content was estimated by a modification ( $9 a$ ) of a fluorescence method (8) by using two DNA-binding fluorescent dyes (bis-benzimide, chromomycin A3) and ethanol-fixed whole cells in Tris-saline- $\mathrm{Mg}$ buffer.

The 16S RNA genes of strains MS1 and MS $32^{\mathrm{T}}$ were sequenced by using the PCR method of Lane et al. (7) and the following forward and reverse primers (kind gifts from Reinhardt Rosson): primers 519r and 907r (7); primers $805 \mathrm{f}$, $342 \mathrm{r}, 8 \mathrm{f}$ ("fD2"), and 1492rL ("rP2") of Weisberg et al. (13); and primer 530f (GTGCCAGCMGCCGCGG), as suggested by D. Distel. The final PCR mixtures contained $2 \mathrm{U}$ of Taq polymerase (Promega, Madison, Wis.), $2.75 \mathrm{mM}$ $\mathrm{MgCl}_{2}, 7 \%$ glycerol, $3 \%$ formamide, each deoxynucleoside triphosphate at a concentration of $0.2 \mathrm{mM}, 20 \mathrm{pmol}$ of each primer, and $50 \mu \mathrm{g}$ of template. The Perkin-Elmer model 480 thermal cycler conditions used were $3 \mathrm{~min}$ at $94^{\circ} \mathrm{C}$, followed by 30 cycles consisting of $1 \mathrm{~min}$ at $50^{\circ} \mathrm{C}, 1 \mathrm{~min}$ at $74^{\circ} \mathrm{C}$ and $1 \mathrm{~min}$ at $94^{\circ} \mathrm{C}$. The amplified fragments were purified on $1 \%$ agarose, and the slices were cleaned with Wizard PCR Preps (Promega) and sequenced with an Applied Biosystems model ABI 373a automated sequencer. The sequences obtained were aligned by using Sequencer 3.0 (Gene Codes Corp., Ann Arbor, Mich.) and were used to construct trees. The trees were constructed by performing a parsimony analysis with the PAUP program (10).

\section{RESULTS AND DISCUSSION}

All of the strains were motile rods. Each cell possessed a single polar flagellum (Fig. 1), which was not surrounded by a sheath like that found in some other luminous bacteria (2). An unsheathed flagellum is characteristic of the genera Shewanella, Alteromonas, and Pseudoalteromonas (4, 6). None of the strains could ferment sugars, which led us initially to suspect that these organisms were strains of $S$. hanedai. $S$. hanedai is psychrophilic with an optimum growth temperature of 15 to $20^{\circ} \mathrm{C}$. The MS strains grew at $4^{\circ} \mathrm{C}$, grew best at $25^{\circ} \mathrm{C}$, and did not grow at $30^{\circ} \mathrm{C}$. Thus, to determine if these organisms were related, all of the phenotypic characteristics (see above) were tested and coded for a cluster analysis. This analysis emphasized substrate utilization in the Biolog GN plates (95 of 131 traits). The UPGMA cluster analysis in which Euclidean distances were used showed that the MS strains had relatively high levels of similarity $(>92 \%)$. The UPGMA distance matrix was analyzed by multidimensional scaling in two dimensions (Fig. 2), which showed that the MS strains were clearly sepa-

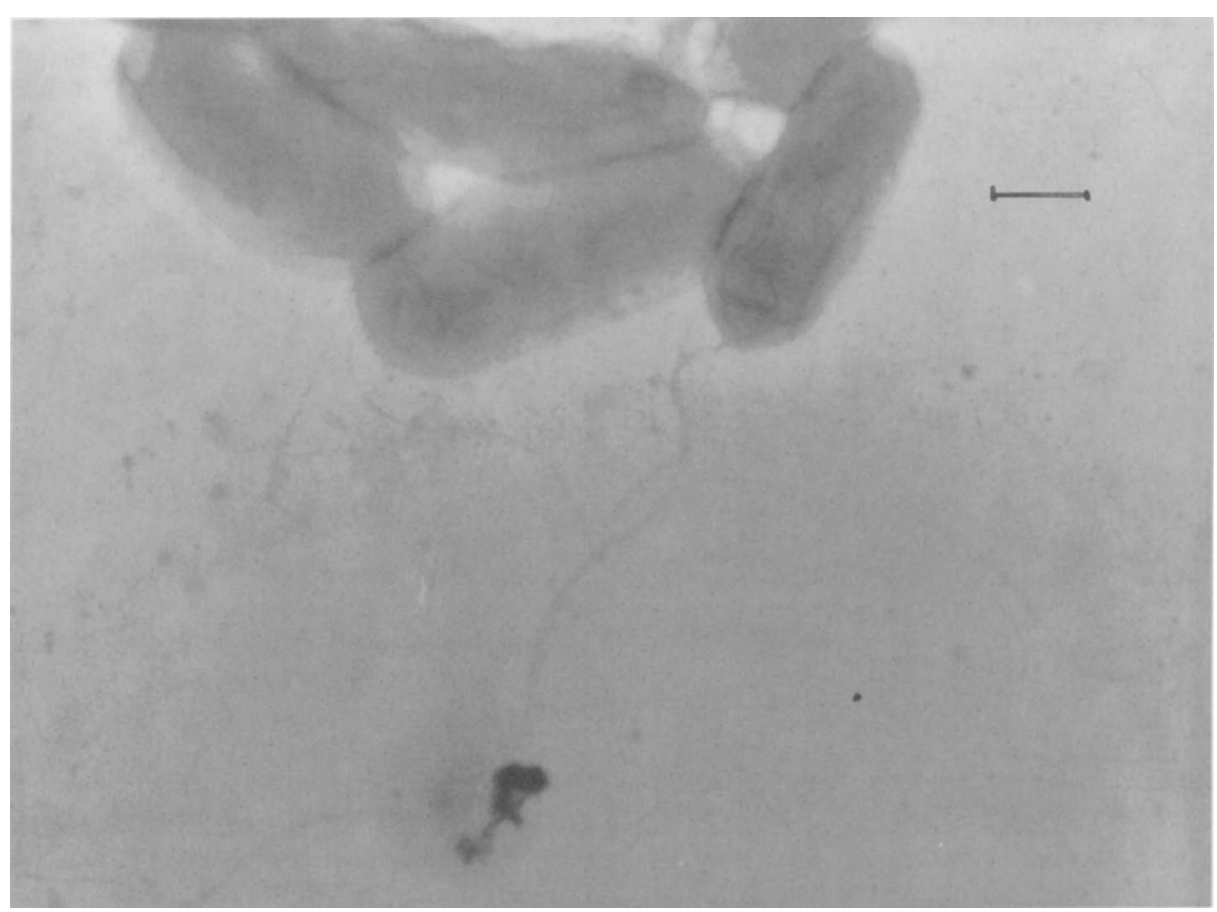

FIG. 1. Transmission electron micrograph of $S$. woodyi $\mathrm{MS}_{32}{ }^{\mathrm{T}}$ stained with $1 \%$ uranyl acetate on a Formvar-coated grid. Bar $=0.5 \mu \mathrm{m}$. 


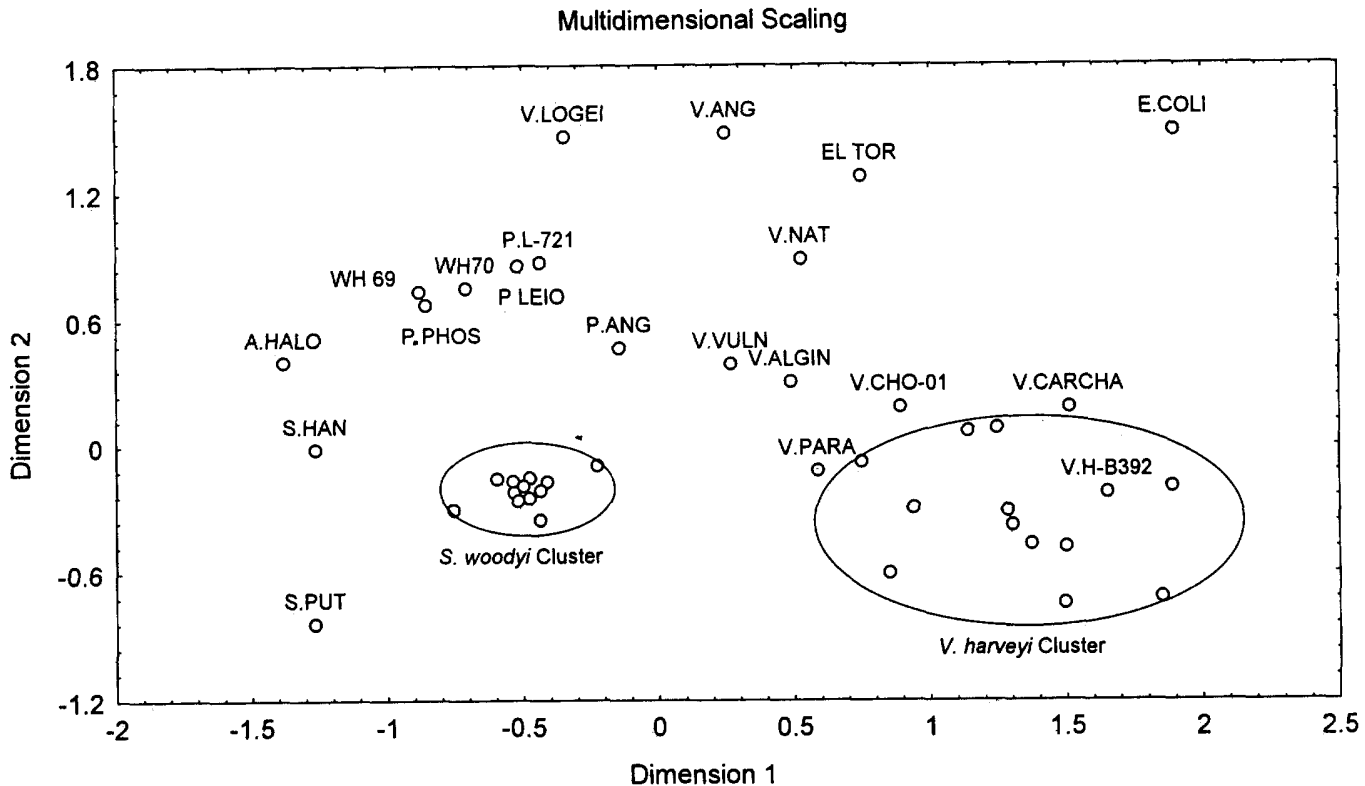

FIG. 2. Multidimensional scaling analysis of MS strains ( $S$. woodyi cluster) and previously described luminous bacteria, performed by using the Euclidean distance matrix and all of the traits listed in the text. All known strains are listed in Table 1. Abbreviations: A.HALO, Alteromonas haloplanktis; E.COLI, Escherichia coli; P.ANG, Photobacterium angustum; P.LEIO, Photobacterium leiognathi; P.L-721, Photobacterium leiognathi 721; P.PHOS, Photobacterium phosphoreum; S.HAN, Shewanella hanedai; S.PUT, Shewanella putrefaciens; V.ALGIN, Vibrio alginolyticus; V.ANG, Vibrio anguillarum; V.CARCHA, Vibrio carchariae; V.CHO-01, Vibrio cholerae O1; EL TOR, Vibrio cholerae El Tor; V.H-B392, Vibrio harveyi B-392; V.LOGEI, Vibrio logei; V.NAT, Vibrio natriegens; V.PARA, Vibrio parahaemolyticus; V.VULN, Vibrio vulnificus.

TABLE 2. Fatty acid profiles, as determined by the MIDI method

\begin{tabular}{|c|c|c|c|c|c|c|}
\hline \multirow[b]{2}{*}{ Fatty acid } & \multicolumn{6}{|c|}{$\%$ in: } \\
\hline & 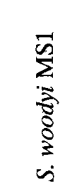 & 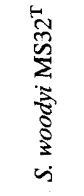 & 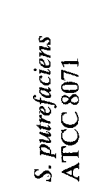 & 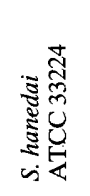 & 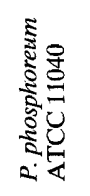 & 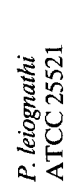 \\
\hline$\overline{12: 0}$ & 4.64 & 4.13 & 2.76 & 6.04 & 5.55 & 4.75 \\
\hline $11: 03 \mathrm{OH}$ & & & 0.48 & & & \\
\hline $13: 0$ iso & 10.5 & 10.04 & 3.74 & 14.07 & & \\
\hline $13: 0$ & 1.09 & 0.87 & 1.15 & 0.94 & & \\
\hline $12: 03 \mathrm{OH}$ & 2.06 & 1.93 & 1.49 & 3.94 & 5.13 & 3.38 \\
\hline $14: 0$ iso & 0.54 & & & & & \\
\hline 14:0 & 6.42 & 4.65 & 1.26 & 10.66 & 4.66 & 4.81 \\
\hline $13: 0$ iso $3 \mathrm{OH}$ & 5.35 & 6.54 & 2.97 & 6.14 & & \\
\hline $15: 0$ iso & 14.32 & 19.53 & 22.56 & 7.19 & & \\
\hline $15: 0$ anteiso & 0.40 & 0.65 & 0.37 & & & \\
\hline $15: 0$ & 4.80 & 4.05 & 4.85 & 3.35 & & \\
\hline $16: 0$ iso & & & 0.88 & & & \\
\hline $16: 1 \mathrm{~B}$ & 1.09 & 1.18 & 0.051 & 1.55 & & \\
\hline $16: 1$ cis 9 & 16.19 & 17.26 & 18.25 & 23.40 & 55.05 & 38.31 \\
\hline $16: 0$ & 26.07 & 20.81 & 12.91 & 17.85 & 20.36 & 25.05 \\
\hline $15: 0$ iso $3 \mathrm{OH}$ & & & 0.53 & & & \\
\hline $17: 1$ iso $F$ & & & 0.80 & & & \\
\hline $17: 0$ iso & 0.74 & 1.66 & 2.19 & 0.77 & & \\
\hline $17: 1 \mathrm{~B}$ & 1.55 & 2.15 & 9.07 & 1.37 & & \\
\hline 17:0 cyclo & & & & & & 0.63 \\
\hline $17: 0$ & 1.41 & 1.30 & 2.85 & & & \\
\hline $16: 03 \mathrm{OH}$ & & & 0.41 & & & \\
\hline $18: 1$ cis 9 & 1.03 & 0.98 & 2.12 & 0.77 & & \\
\hline $18: 0$ & & & 0.76 & & & 0.61 \\
\hline $20: 0$ iso & 0.74 & 0.68 & & & & \\
\hline Unknown 12.486 & & & & & 1.29 & 0.42 \\
\hline
\end{tabular}

rated from $S$. hanedai, as well as other known luminous bacteria. The $\mathrm{G}+\mathrm{C}$ content of $\mathrm{MS} 32^{\mathrm{T}}$ was determined to be 39 mol\% by using the modified fluorescence method. The $\mathrm{G}+\mathrm{C}$ content of $S$. hanedai DNA is $45.2 \mathrm{~mol} \%$ (6). Thus, the new MS strains could be considered members of a separate taxon on phenetic grounds.

As a test of taxonomic validity, several strains (MS1, MS32 ${ }^{\mathrm{T}}$, MS36, MS38) were analyzed with the MIDI fatty acid analysis system and compared to other marine bacteria (Table 2). Like $S$. putrefaciens and $S$. hanedai, the MS strains had relatively high concentrations of 13:0 iso and 15:0 iso fatty acids, which were not present in vibrios (data not shown) or Photobacterium species. Furthermore, the ratio of $16: 1$ cis 9 to $16: 0$ was skewed

TABLE 3. Reactions of luxA probes prepared from $V$. harveyi and $S$. woodyi with chromosomal DNAs of luminous bacteria

\begin{tabular}{|c|c|c|c|c|}
\hline \multirow[b]{3}{*}{ Organism(s) } & \multicolumn{4}{|c|}{ Reaction with $\operatorname{lu} x A$ probe from: } \\
\hline & \multicolumn{2}{|c|}{ V. harveyi B-392 } & \multicolumn{2}{|c|}{ S. woodyi MS32 } \\
\hline & 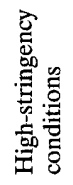 & 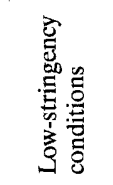 & 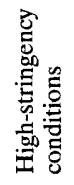 & 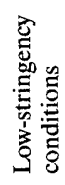 \\
\hline V. harveyi MAV & + & + & + & + \\
\hline S. woodyi MS32 ${ }^{\mathrm{T}}$ & - & + & + & + \\
\hline S. woodyi MS1 & - & - & + & + \\
\hline$V$. fischeri ATCC 7744 & - & - & - & - \\
\hline V. logei MS12 & - & + & - & + \\
\hline Six nonluminous vibrios & - & $3+, 3-^{a}$ & - & - \\
\hline
\end{tabular}

${ }^{a}$ The American Type Culture Collection type cultures that hybridized with the $V$. haveyi probe were the $V$. damsela, $V$. natriegens, and $V$. parahaemolyticus cultures, whereas those that did not hybridize were the $V$. anguillarum, $V$. alginolyticus, and $V$. cholerae cultures. 


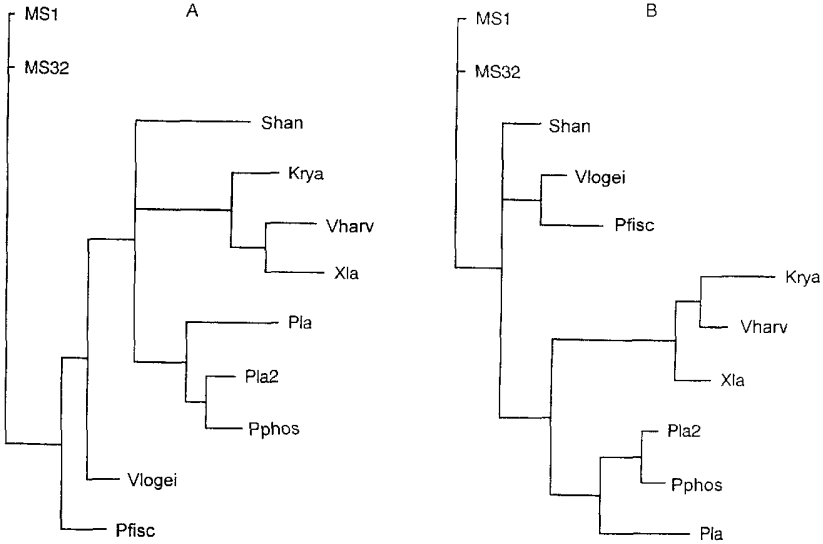

FIG, 3. Unrooted phylogenetic trees based on $l u x A$ sequences. (A) Tree based on direct $\operatorname{lux} A$ sequences. (B) Tree based on translated luxA sequences analyzed by PAUP. Abbreviations: Krya, Krytophaneron alfredi symbiont; Vharv, Vibrio haveyi; Xla, Xenorhabdus (Photorhabdus) luminescens; MS1 and MS32, S woodyi MS1 and MS32 ${ }^{\mathrm{T}}$, respectively; Shan, Shewanella hanedai; Vlogei, Vibrio logei; Pla2 and Pla, two strains of Photobacterium leiognathi; Pphos, Photobacterium phosphoreum; Pfisc, Vibrio (Photobacterium) fischeri.

toward the unsaturated fatty acid (1.4 to 2.7$)$ in the vibrios, Photobacterium species, $S$. putrefaciens, and $S$. hanedai but skewed toward the saturated fatty acid $(0.62$ to 0.83$)$ in $S$. woodyi. Thus, the fatty acid analysis showed that $S$. woodyi is unique but is related to other shewanellae.

lux $A$ hybridization data also confirmed the unique taxonomic nature of the MS strains. The primers of Wimpee et al. produced a PCR product with DNAs from MS strains only if

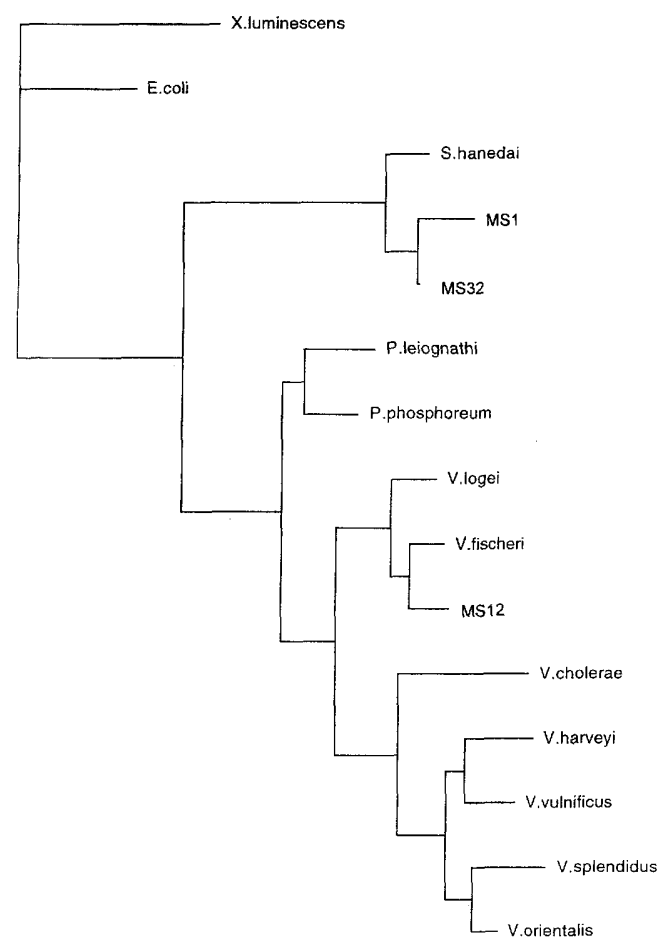

FIG. 4. Unrooted phylogenetic tree based on 16S rRNA sequences analyzed by PAUP. Strains from GenBank are designated with species names; MS1 and MS32 are S. woodyi strains; and MS12 is a V. loge $i$ strain (unpublished sequence). The GenBank accession numbers are as follows: $E$. coli, J10695; $P$. leiognathi, 74686; $P$. phosphoreum, 74687; Photobacterium luminescens, 3368; $S$. hanedai, 103207T; V. cholerae, X74697; V. vulnificus, X74726; Vibrio splendidus, X74724; Photobacterium fischeri X74702; V. harveyi, X74706; and V. logei, X74708.

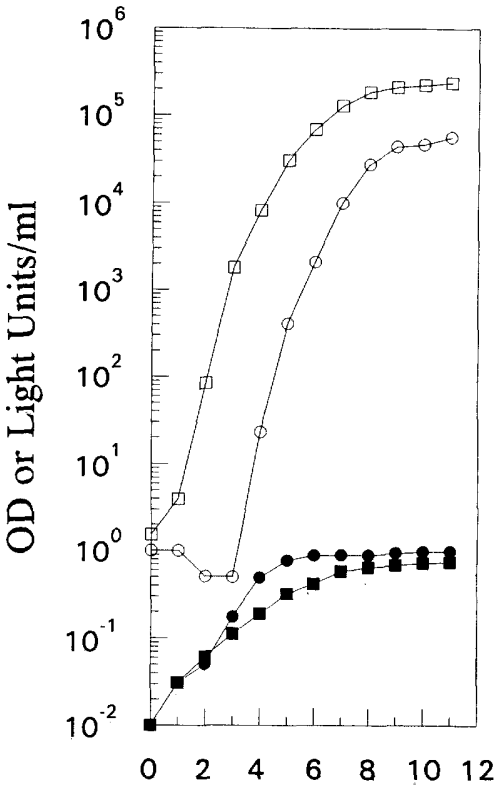

Hours

FIG. 5. Growth (closed symbols) and luminescence (open symbols) of MS25 in SMA broth at $25^{\circ} \mathrm{C}$. Conditioned medium ( $\square$ and $\mathbf{a}$ ) was prepared by growing MS25 in unconditioned SMA broth ( $\bigcirc$ and $O$ ) to an optical density at $660 \mathrm{~nm}$ of 1.0 and then centrifuging the culture $(12,000 \mathrm{rpm}$ [Eppendorf Microfuge], $5 \mathrm{~min}$, $20^{\circ} \mathrm{C}$ ) and sterilizing the supernatant by filtration through a $0.2-\mu \mathrm{m}$-pore-size membrane filter (Millipore). Both media were inoculated from the same culture to an initial optical density at $660 \mathrm{~nm}$ of 0.01 and incubated with shaking (200 rpm) at $25^{\circ} \mathrm{C}$. OD, optical density.

low-stringency annealing temperature $\left(35^{\circ} \mathrm{C}\right)$ was used. This indicated that there may be sequence differences in the primer regions (a 23-mer and a 26-mer) between $S$. woodyi and other luminous bacteria. When an MS strain DNA PCR product was used as the PCR template, a good yield was obtained under high-stringency conditions $\left(55^{\circ} \mathrm{C}\right)$ because the PCR product had the Wimpee et al. primer sequences at each end. Probes from MS32 ${ }^{\mathrm{T}}$ DNA and $V$. harveyi $\mathrm{B} 392$ DNA that were random prime labeled with digoxigenin were prepared and reacted with chromosomal DNAs prepared from two MS strains and known American Type Culture Collection strains under low- and high-stringency conditions (14). Our results (Table 3) show that the MS strain probe reacted under high-stringency conditions only with other MS strain DNAs but under low-stringency conditions reacted with $V$. harveyi and Vibrio logei and not with Vibrio fischeri or other nonluminous vibrios, whereas the $V$. harveyi probe reacted with five species ( $S$. woodyi, $V$. logei, Vibrio damsela, Vibrio natriegens, Vibrio parahaemolyticus) under low-stringency conditions.

The sequences in the 740-bp sequence of $\operatorname{lux} A$ subtended by the primers of Wimpee et al. (11) from MS1 (639 bp) and from forward (206-bp) and reverse (119-bp) sections of the MS32 sequence were compared to other known luxA sequences obtained from GenBank and analyzed with the PAUP program. Figure 3A shows the most-parsimonious unrooted consensus tree at the nucleotide level which demonstrated that for this $\operatorname{lu} x A$ region, the two MS strains clustered together and were more closely related to $V$. logei and $V$. (Photobacterium) fischeri than the other luminous bacteria, including $S$. hanedai. At the translated amino acid level, the MS1 and MS32 ${ }^{\mathrm{T}} \operatorname{lu} \times A$ sequences clustered closer to $S$. hanedai and still remained close to $V$. fischeri and $V$. logei (Fig. 3B). 
TABLE 4. Sodium requirement for luciferase synthesis by $S$. woodyi $\mathrm{MS} 32^{\mathrm{T}}$ growing in SMA broth at $25^{\circ} \mathrm{C}$ with shaking $(200 \mathrm{rpm})$

\begin{tabular}{ccc}
\hline $\begin{array}{c}\text { \% of } \mathrm{NaCl} \text { concn } \\
\text { in seawater }\end{array}$ & $\begin{array}{c}\text { Maximum growth (optical } \\
\text { density at } 660 \mathrm{~nm} \text { ) }\end{array}$ & $\begin{array}{c}\text { Luminescence } \\
\text { (light units) }^{b}\end{array}$ \\
\hline 50 & 0.99 & 0.15 \\
75 & 1.23 & 12,640 \\
100 & 1.25 & 608,000 \\
125 & 1.01 & 2,702 \\
150 & 0.94 & 0.15 \\
175 & 0.148 & 0 \\
\hline
\end{tabular}

${ }^{a}$ A value of $100 \%$ was equivalent to $0.517 \mathrm{M}$; the concentrations of all other sea salts were the same as the concentrations in SMA.

${ }^{b}$ One light unit was equivalent to $3.9 \times 10^{6}$ photons $\mathrm{s}^{-1} \mathrm{ml}^{-1}$.
Figure 4 shows that the 16S RNA sequence data for MS1 and MS32 $^{\mathrm{T}}$ (GenBank accession numbers AF003548 and AF003549) indicate a closer relationship between MS1 and $\mathrm{MS}_{2}{ }^{\mathrm{T}}$ sequences and the $S$. hanedai sequence (GenBank accession no. 103207T) than is evident from the lux $A$ sequence. Furthermore, the luminous shewanella 16S RNA sequences form a group that is separate from the 16S RNA sequences of all of the other luminous bacteria.

$S$. woodyi has a kinetically distinct luciferase (the apparent first-order decay constants at $25^{\circ} \mathrm{C}$ were $0.241 \mathrm{~s}^{-1}$ with dodecanal and $0.240 \mathrm{~s}^{-1}$ with decanal in the presence of $2 \mathrm{mg}$ of bovine serum albumin per $\mathrm{ml}$ ). These kinetics are intermediate between the kinetics of the kinetically slow luciferases of $V$. harveyi and the kinetics of the fast luciferases of the Photobac-
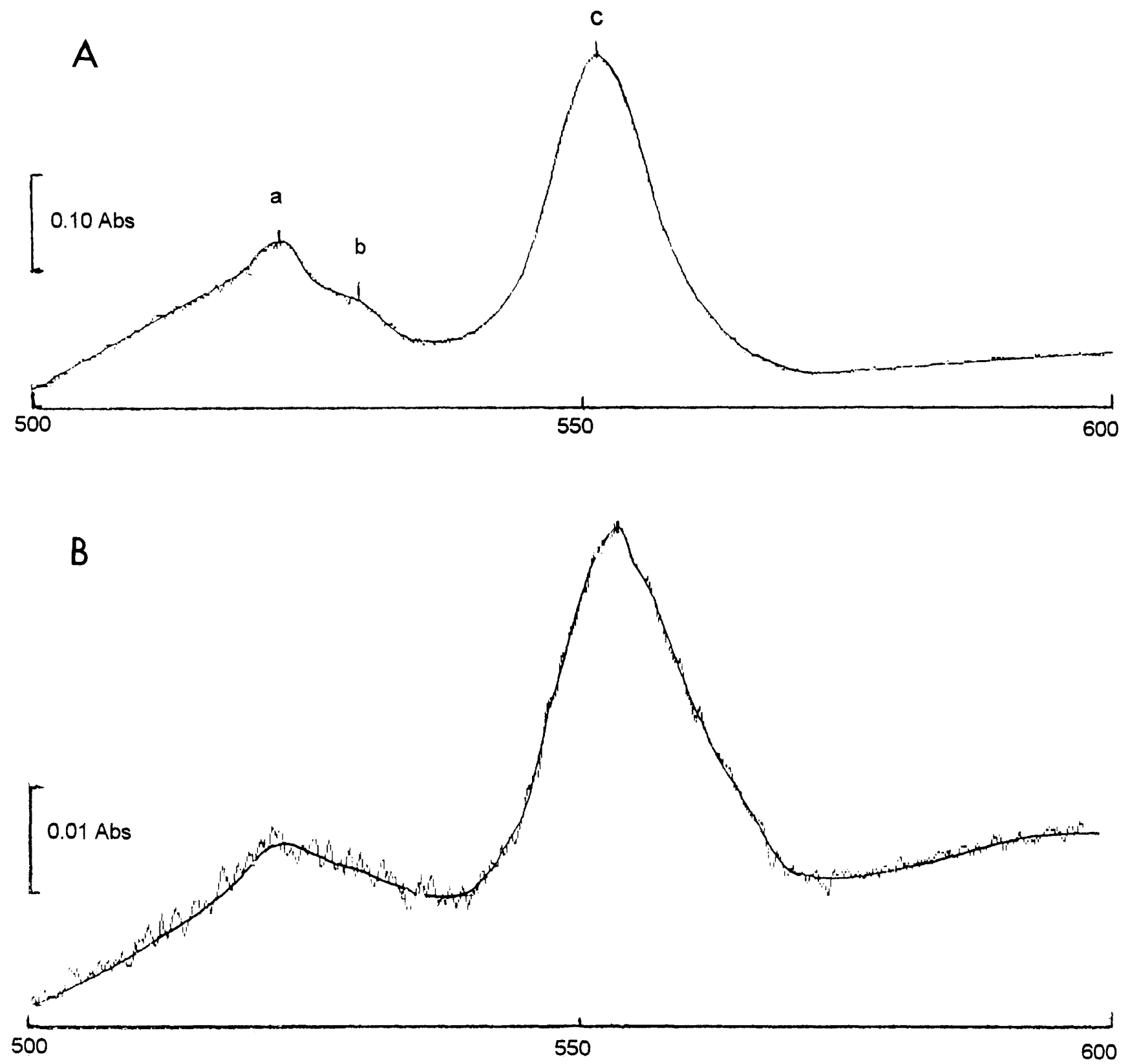

FIG. 6. Dithionite-reduced-minus-hydrogen-peroxide-oxidized spectra of $\mathrm{MS}_{2}{ }^{\mathrm{T}}$ whole cells in $0.05 \mathrm{M}$ Tris (pH 8.0) containing $0.01 \mathrm{M} \mathrm{MgCl}$. (A) Difference spectrum for aerobically grown cells. Bar = optical density of 0.1 . (B) Difference spectrum for nitrate-anaerobic cells. The following wavelengths are indicated on the spectrum: a, $522 \mathrm{~nm} ; \mathrm{b}, 530 \mathrm{~nm} ; \mathrm{c}, 551 \mathrm{~nm}$. Bar = optical density of 0.01 . 
TABLE 5. Comparison of $S$. hanedai and $S$. woodyi

\begin{tabular}{|c|c|c|}
\hline Trait & S. woodyi & S. hanedai ${ }^{a}$ \\
\hline Respiratory & + & + \\
\hline Fermentative & - & - \\
\hline Oxidase & + & + \\
\hline Growth at $4^{\circ} \mathrm{C}$ & + & + \\
\hline Growth at $30^{\circ} \mathrm{C}$ & - & - \\
\hline Amylase $^{h}$ & $+^{c}$ & - \\
\hline Gelatinase & + & + \\
\hline Lipase $^{b}$ & - & + \\
\hline Chitinase $^{h}$ & - & + \\
\hline \multicolumn{3}{|l|}{ Biolog substrates } \\
\hline D-Mannose & - & - \\
\hline D-Galactose & + & + \\
\hline Sucrose & - & - \\
\hline Cellobiose $^{b}$ & + & - \\
\hline D-Glucuronate ${ }^{b}$ & + & - \\
\hline$N$-Acetylglucosamine ${ }^{b}$ & - & + \\
\hline Glycerol & - & - \\
\hline Acetate & + & + \\
\hline$\alpha$-Ketoglutarate ${ }^{b}$ & + & - \\
\hline Propionic acid & + & + \\
\hline Succinic acid $b$ & + & - \\
\hline Citrate & - & - \\
\hline L-Alanine & + & + \\
\hline D-Alanine & - & - \\
\hline L-Threonine & + & + \\
\hline L-Leucine & + & + \\
\hline L-Serine & + & + \\
\hline Putrescine & + & + \\
\hline
\end{tabular}

${ }^{a}$ Data from reference 3 were confirmed in this study by using the American Type Culture Collection type strain.

Differentiating characteristic.

Of the 34 strains tested, 27 were positive.

terium group. The $S$. woodyi luciferase kinetics are nearly the same as the $V$. harveyi luciferase kinetics with decanal, yet unlike the kinetics of $V$. harveyi luciferase, which exhibits very slow decay kinetics with dodecanal. The $S$. woodyi luciferase decay kinetics with dodecanal are almost identical to the decanal decay kinetics, a situation which is similar to the situation with the fast luciferases of the Photobacterium group.

$S$. woodyi synthesized luciferase late in batch growth and apparently could have autoinductive control of luciferase synthesis because bacteria freshly inoculated into "conditioned" media showed no lag in luciferase synthesis (Fig. 5). Even though the bacteria could grow over a wide range of salinities (Table 4), luciferase synthesis showed a pronounced requirement for sodium (at $1 \times$ seawater strength), like strains of Photobacterium phosphoreum $(3,5)$.

$S$. woodyi is a prototroph that grows well on single-carbonsource media with ammonium as the nitrogen source. Anaerobically, the MS strains grew with nitrate or nitrite as the terminal electron acceptor and grew slowly with fumarate as the terminal electron acceptor. Whether the organisms are grown aerobically or anaerobically, the reduced-minus-oxidized cytochrome spectra of whole cells have a single $\alpha$ peak at $552 \mathrm{~nm}$, indicating a high cytochrome $c$ content (Fig. 6). There were no cytochrome $a, d$, or $o$ peaks. The very high cytochrome $c$ content was reflected in colony coloration; MS strains growing on SMA all had a pinkish orange tint identical to that of $S$. putrefaciens growing on brain heart infusion agar.

Traits that separate $S$. woodyi from $S$. hanedai are indicated in Table 5; $S$. woodyi possesses amylase, lipase, and chitinase activities and is positive in Biolog reactions with cellobiose, D-glucuronate, $N$-acetylglucosamine, $\alpha$-ketoglutarate, and suc- cinic acid. Both Shewanella species were isolated from intermediate depths in the ocean $(S$. hanedai from Arctic sediments, Antarctic and Sannich Inlet, and British Columbia seawater at depths of 100 to $220 \mathrm{~m}$; $S$. woodyi from the Alboran Sea), but the two species appear to be taxonmically separate.

Description of Shewanella woodyi sp. nov. Shewanella woodyi (wood'y.i. M.L. gen. n. woodyi, of Woody, in honor of the American biologist J. Woodland Hastings) cells are gram-negative, obligately respiratory, luminescent, marine, nonsporulating rods $(0.4$ to 1.0 by 1.4 to $2.0 \mu \mathrm{m})$, and each cell possess a single, unsheathed, polar flagellum. The cells use oxygen, nitrate, and nitrite as terminal electron acceptors and possess catalase and oxidase activities. They grow at 4 to $25^{\circ} \mathrm{C}$ but not at $30^{\circ} \mathrm{C}$. All strains produce gelatinase, and most strains $(27$ of 34 strains) produce amylase, but they do not produce lipase, chitinase, or agarase. They metabolize D-galactose, cellobiose, D-glucuronic acid, acetate, $\alpha$-ketoglutarate, propionate, succinate, L-alanine, L-threonine, L-leucine, L-serine, and putrescine. The $\mathrm{G}+\mathrm{C}$ content of the DNA is $39 \mathrm{~mol} \%$. The type strain is ATCC 51908 (= MS32).

\section{ACKNOWLEDGMENTS}

We thank the Office of Naval Research (grant ONR N00014-89-J1736 to J.F.C. and grants ONR N00014-90-J-1819 and N00014-91C6007 to E.A.W.) for funding that resulted in the original samples from which the strains of the new species were isolated.

\section{REFERENCES}

1. Akagawa-Matsushita, M., T. Itoh, Y. Katayama, H. Kuraishi, and K. Yamasato. 1992. Isoprenoid quinone composition of some marine Alteromonas, Marinomonas, Deleya, Pseudomonas and Shewanella species. J. Gen. Microbiol. 138:2275-2281.

2. Allen, R. D., and P. Baumann. 1971. Structure and arrangement of flagella in species of the genus Beneckea and Photobacterium fischeri. J. Bacteriol. 107:295-302.

3. Dunlap, P. 1985. Osmotic control of luminescence and growth in Photobacterium leiognathi from pony fish light organs. Arch. Microbiol. 141:41-50.

4. Gauthier, G., M. Gauthier, and R. Christen. 1995. Phylogenetic analysis of the genera Alteromonas, Shewanella, and Moritella using genes coding for smallsubunit rRNA sequences and division of the genus Alteromonas into two genera, Alteromonas (emended) and Pseudoalteromonas gen. nov., and proposal of twelve new species combinations. Int. J. Syst. Bacteriol. 45:755-761.

5. Hastings, J. W., J. Makemson, and P. Dunlap. 1987. How are growth and luminescence regulated independently in light organ symbioses? Symbiosis 4:3-24.

5a.International Journal of Systematic Bacteriology. 1981. Validation of the publication of new names and new combinations previously effectively published outside the IJSB. List no. 7. Int. J. Syst. Bacteriol. 31:382-383.

5 b.International Journal of Systematic Bacteriology. 1986. Validation of the publication of new names and new combinations previously effectively published outside the IJSB. List no. 20. Int. J. Syst. Bacteriol. 36:354-355.

6. Jensen, M. J., B. M. Tebo, P. Baumann, M. Mandel, and K. H. Nealson. 1980. Characterization of Alteromonas hanedai (sp. nov.), a non-fermentative luminous species of marine origin. Curr. Microbiol. 3:311-315.

7. Lane, D. B., B. Pace, G. L. Olsen, D. A. Stahl, and N. R. Pace. 1985. Rapid determination of $16 \mathrm{~S}$ rRNA sequences for phylogenetic analysis. Proc. Natl. Acad. Sci. USA 82:6955-6959.

8. Lutz, L. H., and A. A. Yayanos. 1985. Spectrofluorometric determination of bacterial DNA base composition. Anal. Biochem. 144:1-5.

9. MacDonell, M. T., and R. R. Collwell. 1985. Phylogeny of the Vibrionaceae, and recommendation for two new genera, Listonella and Shewanella. Syst. Appl. Microbiol. 6:171-182.

9a.Makemson, J. C. Unpublished data.

10. Makemson, J. C., J. W. Hastings, and J. M. E. Quirke. 1992. Stabilization of luciferase intermediates by fatty amines, amides and nitriles. Arch. Biochem. Biophys. 294:361-366.

11. Reichelt, J. L., and P. Baumann. 1973. Taxonomy of marine, luminous bacteria. Arch. Mikrobiol. 94:283-330.

12. Swofford, D. L. 1991. PAUP: phylogenetic analysis using parsimony, version 3.0s. Illinois Natural History Survey, Champaign.

13. Weisberg, W. G., S. M. Barns, D. A. Pelletier, and D. J. Lane. 1991. 16S ribosomal DNA amplification for phylogenetic study. J. Bacteriol. 173:697-703.

14. Wimpee, C. F., T.-L. Nadeau, and K. H. Nealson. 1991. Development of species-specific hybridization probes for marine luminous bacteria by using in vitro DNA amplification. Appl. Environ. Microbiol. 57:1319-1324. 